\title{
PAX MAGNA SAU DESPRE SIMPATIA DEMON-CREATOR
}

DOI: $10.2478 / \mathrm{clb}-2019-0021$

Ioana Jeler

\section{Universitatea de Medicină, Farmacie, Științe și Tehnologie, Târgu-Mureș}

\begin{abstract}
One of the most representative theme in the works of Lucian Blaga is knowledge and the way it is reflected in the unconscious. He is known for the different meanings given to this knowledge, proposing a new path for the understanding of everything around us, starting from the inner of human soul to the world genesis. This paper will show this specific process of Blaga, in one poem ,Pax Magna”.
\end{abstract}

Key-words: knowledge, metaphor, genesis, God, Demon, peace.

Lucian Blaga plasează drept poezie de deschidere a creaţiilor sale poetice Eu nu strivesc corola de minuni a lumii, ars poesis, care susține ideea unei poezii ca formă de cunoaștere, devenind un îndemn spre gnoză. Poemele următoare se supun aceleași teme, cea a cunoașterii, așadar Blaga construiește un spațiu al organicității. Ideile și conceptele filosofice își găsesc ecou în substanța poetică.

Sensul poetic este generat de metafora revelatorie. Poetul reușește nu doar să plaseze în versuri această figură, ci să o și potențeze prin mit. Evidențiind specificul poeticului, Nicolae Manolescu afirmă:,,Orizontul mitului este similar celui al metaforei: mijloc de cunoaștere analogică a lumii prin care, în loc să fie reduse, neînțelesurile se schimbă în înțelesuri și mai mari." În cadrul volumului de debut, poeziile lui Blaga urmăresc tocmai această tehnică analogică, prin care parcurge atât cunoașterea lumii, cât și a sinelui, folosind elemente mitologice din sfera arhaică, religioasă și filosofice, invitând, mai apoi, prin versuri, la o nouă cunoaștere deschisă perspectivei ontos-urilor. Dintre toate metaforele revelatorii existente la Blaga, lumina ocupă un loc aparte în glosaru-i poetic; această metaforă, simbol al întregului volum, conturează sacralitatea, lumina poetului ,sporește a lumii taină”. De asemenea, este și un indice al contemplației, un liant al sufletului uman cu natura primă, cu începuturile, sugerând calea ascendenței spre divin.

Spre finele volumului Poemele luminii, se află poemul Pax Magna. Cu o rezonanță puternică în limba latină, titlul anunță o „,mare pace”. De-a lungul poemului, starea pe care o indică titlul pare a fi mai degrabă o joacă metaforică, care contribuie și ea la percepția afectivă a textului.

Contrar echilibrului pe care îl instaurează titlul, poezia se deschide cu

${ }^{1}$ Nicolae Manolescu, Istoria critică a literaturii române, Ed. Paralela 45, 2008, Pitești, p.686. 
o interogație:,De ce?”, care, ulterior, se repetă; prima parte a poemului denotă prin urmare, o stare de confuzie care va fi accentuată mai apoi de o întreagă dihotomie existențială.

$\mathrm{Al}$ doilea vers al poeziei deschide o primă portiță interpretativă prin metafora revelatorie „un picur de dumnezeire pe pământ” unde spaţiul se înfățișează în dublă ipostază, prin sacru și profan. Această antonimie divinpământesc, susținută de verbul sinecdotic ,îngenunchez" trimite spre geneză, întâlnirea cea dintâi a omului cu sacralitatea sau întruparea lui Dumnezeu în om². Comparația ,în fața mea ca-n fața unui idol” evidențiază analogia chipidol, omul conștientizează prezența divinului în creație, astfel se remarcă o translare a profanului în sacru, tocmai prin acest picur de dumnezeire. Mai mult: ,[...] transcendentul şi contingentul se încarcă reciproc de virtuţile sacrului, venind unul spre celălalt fără a ieși din orizontul misterului și al revelării."”3

Cea de-a doua interogaţie pune accent pe înecarea eului, fapt care se întâmplă într-un imagistic latent cunoaşterii, simbolizat prin prezența luminii. Verbul „se-neacă” sugerând o împotmolire. Alăturată lexemului „eu”, într-un cadru atât de prielnic autocunoaşterii, semantica înecului propune o receptare reversibilului mișcării ${ }^{4}$. Conversiunea pronumelui „eu” (,eul”) trimite spre un semantism lăuntric, astfel putem vorbi despre un sine poetizat. Drept urmare, principiul lui Novalis conform căruia: „orice coborâre în sine este în acelaşi timp și înălțarea spre realitatea exterioară" ${ }^{\circ}$, se regăsește și în poezia lui Blaga.

În versurile următoare, întâlnirea cu realitatea exterioară este susținută de simboluri așezate disciplinat în poezie. Un aspect definitoriu îl prezintă epitetul evocator „nopți adânci” care amplifică profunzimea coborârii în sine, în adâncime. Metafora „sori îndepărtați s-aprind pe cer” poate avea rădăcini în fondul arhaic a lui Lucian Blaga, întrucât în unele credințe ale poporului român, soarele este „steaua diavolului”, deoarece ,[...] făcând Dumnezeu de toate şi împărțindu-le, s-a apucat să împartă luna, soarele şi stelele. Ca să nu creadă că-1 înșală, Dumnezeu 1-a lăsat să-și aleagă. Diavolul și-a luat soarele. ${ }^{, 6}$ Astfel, printr-o metaforă revelatorie,tainic se sugerează, întâlnirea Dumnezeu-Satana prin ,sori-pe cer”.

La nivel lexical, sunt folosite inversiuni semnificative, antinomii precum: vară-iarnă, zi-noapte, lumină-întuneric, care nu au doar valoare stilistică, în sensul impunerii câmpurilor semantice ale întunericului și luminii, ci și prelungiri simbolice către mister și cunoaștere. Prin urmare, în

\footnotetext{
${ }^{2}$ Lucian Blaga, „Spațiul mioritic” (din Trilogia culturii), Ed. Humanitas, 2011, București, p. 177.

${ }^{3}$ Vasile Fanache, Chipuri tăcute ale veșniciei în lirica lui Blaga, Ed. Dacia, Cluj-Napoca, 2003, p.66.

${ }^{4}$ Apud Eugen Todoran, Lucian Blaga. Mitul poetic vol. 2, Ed. Facla, 1983, Timișoara, p. 49.

${ }^{5}$ Eugen Todoran, op. cit., p. 49.

${ }^{6}$ Eugen Todoran, op. cit., p. 53.
} 
simultaneitate cu primul poem, Eu nu strivesc corola de minuni a lumii, în „marea pace”, persistă aceeași preferință a autorului spre conservarea misterului, întrucât tulburarea eului se arată odată cu încercarea omului de a da sens unor taine universale, cum ar fi: angelicul și demonicul. În acest fel, cea de-a treia interogație surprinde prin accentuata antonimie Demon-Creator. De altfel, în observația lui Gilbert Durand, „de la această relație DumnezeuDiavol, în structura imaginarului, se coboară la cea paradisiac-luciferică." ${ }^{7}$

În prima parte a poeziei, umanul este problematizat sub forma a două ipostaze, printr-un paralelism antagonic: omul-,un picur de dumnezeire”, respectiv omul cu dracul-n pieptul său.

La nivel stilistic, alternanța contrariilor în poezie îi conferă lui Lucina Blaga o temelie prielnică crezului ce are să îl expună în versuri. Opţiunea poetului este pentru adeziunea contrariilor într-o ideologie a propriei fiinţe, poezia devenind o scriere directă a (în)scrisului personal.

Motivul umbrei, instituit de către opoziția lumină-întuneric, este unul semnificativ, întrucât îl putem interpreta și sub forma unei prezențe subtextuale a autorului. Percepția filosofului Lucian Blaga se îmbină cu cea a poetului, iar mai apoi acaparează eul. De asemenea, observăm că poezia conține persoana I, singular, fapt care poate trăda, din nou, subiectivitatea filosofului.

Într-o poezie care se deschide prin mitul creației, interferența planului divin cu cel satanic, mai mult, întâlnirea lui Dumnezeu cu Satana chiar în sufletul omului, propun o mai bună conturare a ,eului”, acolo unde „desăvârşirea creației presupune tocmai această prezență a diavolului în om, drept simbol al pământescului, «că dracul nicăieri nu râde mai acasă/ ca-n pieptul meu»»".

Ingambamentul este întrerupt de adverbul ipotetic ,pesemne” aflat la granița dintre cele două scenarii poetice, trimițând semantic la o probabilitate, aducând în centrul poeziei o viziune, o posibilă contemplaţie a eului asupra antroposului. Prezența epitetului adverbal ,învrăjbiți” oferă o conotație negativă, fapt care poate înfiora conștiința eului, în căutarea unor răspunsuri pentru interogațiile precedente în poezie.

Prin asocierea teluricului și a profanului cu prezența satanică, evidențiată în versuri prin contradicția dintre natura umană și cea divină, Eugen Todoran vorbește despre tendința refacerii unității originare prin evidențierea eului duplicitar: așadar ,aceeași ființă are uneori și sensul privirii uneia prin cealaltă"’ . Și iată posibila motivație a repetării ,de ce-urilor”,

\footnotetext{
${ }^{7}$ Gilbert Durand, Structurile antropologice ale imaginarului. Introducere în arhetipologia generală, traducere de Marcel Aderca, postfață Cornel Mihai Ionescu, Ed. Univers Enciclopedic, București, 2000, p. 250.

${ }^{8}$ Cf. Eugen Todoran, idem, p. 57.

${ }^{9}$ Eugen Todoran, Lucian Blaga,mitul poetic vol.1, Ed. Facla, 1981, Timișoara, p. 280.
} 
fiindcă, odată ce o existență este concepută ca ruptă în două, în ,contrarietăți date la limită", se impune refacerea întregului.

Treptat, prima ipostază a poeziei, cea dominată de confuzie, incertitudine este înlocuită printr-un timp reflexiv: alături de poet, medităm asupra existenței.

Semantica formelor temporale de trecut ale verbelor „au înțeles”, „sau împăcat" evocă iterativ geneza, facerea lumii ca efect al pactului dintre Dumnezeu și Satana. De această dată, creația nu mai este una ,pur” divină, ci o împreunare de bine și rău, de divin și demonic.

Toate acestea anunță în registrul imaginarului acea trecere, pe care Eugen Todoran o sublinia: ,[...]de la negative se construiește pozitivul [...]. Este (de fapt) o inversiune a diurnului cu nocturnul" ", în plan simbolic înfățișându-se drept o ,coincidență a contrariilor”, afirmând mai departe: ,[...] o nevoie de a gândi împreună, într-o unitate, ceea ce aparține aceleiaşi existențe, adică lumii ca tot." ${ }^{\prime 1}$. Odată cu această constatare, Blaga dedublează mitul creației, oferindu-i genezei o nouă perspectivă fundamentată pe complementaritatea contrariilor.

Prin poemul Pax Magna, Lucian Blaga ilustrează sufletul uman sub forma unui echilibru, divin-satanic, altfel spus virtute-păcat, propunându-i cititorului o aprofundare a trăirilor care îl ființează:,,iubire, credință-îndoială, minciună".

Cea de-a doua și ultima strofă a poemului propune în incipit două substantive „lumină”, „păcat” legate prin conjuncția „și” cu o semantică evocatoare. Lumina, simbol al sacralității, alături de păcat, rodul trupului ${ }^{12}$, determină sensul poetic al împăcării dintre Demon şi Creator: „Lumina și păcatul/ Îmbrățişându-se s-au înfrățit în mine-ntâia oară”. E un timp al păcii posibil emanat de simpatia Demon-Creator.

Infrățirea dintre lumină și păcat nu reprezintă doar momentul în care Blaga ne oferă un alt mit al genezei, ci şi momentul de maximă elevaţie filosofică în poezie. Potrivit lui Immanuel Kant, autorul construiește în acest punct „,corelaţia ideală”, ,indică legătura ce există între autototalizarea şi autodepăşirea pe de o parte, și chipul sub care omul își revelează ultimele elemente sau coordonate ale misterului". ${ }^{13}$

Trimiterea spre geneză este reluată prin sintagma ,de la-nceputul lumii" și oferă cititorului această nouă închipuire a omului, bun și rău în același trup. Coborârea spre sine este benefică unui transcendentalism al eului poetic.

\footnotetext{
${ }^{10}$ Eugen Todoran, Lucian Blaga, mitul poetic vol.2, Ed. Facla, 1983, Timișoara, p. 49.

${ }^{11}$ Eugen Todoran, op. cit., p. 49.

${ }^{12}$ Eugen Todoran, idem., p. 58.

13 Aurel Codoban, „Un Blaga ignorant: Filosoful religiei”, în Eonul Blaga, Întâiul veac, Ed. Albatros, 1997, București, p. 377.
} 
Un ultim simbol este şarpele. Prezența şarpelui în universul dominat de pace și înfrățire este un plus adus reversiunii simbolurilor tradiţionale. Astfel, „maleficul” șarpelui nu este atât de deosebit de „benefic”. Mircea Eliade vorbește despre o simbolistică a șarpelui unde acesta ilustrează „,două principii ale «totalizării» ca o coincidență a extremelor în divinitate, activă atât sub aspectele ei întunecate (serpentine), cât și luminoase (divine)"14. Prim urmare, divinitatea se alcătuiește prin aspecte întunecate şi luminoase, iar omul, creație a Divinului, se trage inevitabil din bine și din rău, ,printr-o dublă creație a unui Dumnezeu bun și a unui Dumnezeu rău." 15

Prin construcția metaforică „ochii de otravă”, care pândesc adevărul, poetul trimite spre acea „imperfecțiune a creației”, nevoia omului de a-și explica necunoscutul, de a dezlega misterul, înveninându-l astfel. Condiția umană între cele două tipuri de cunoaștere se relevă nu doar în incipitul poemului, ci și la sfârșit.

Pax Magna devine un status-quo al autorului, o premisă postulată în titlul poemului. Marea pace este conștientizarea binelui și a răului existente în creația divină. Această metaforă ezoterică a poeziei evidenţiază o structură a sacrului, respectiv bipolaritatea, drept o metodă a cunoașterii prin ,reintegrarea contrariilor" în lume ca tot. Metaforele revelatorii și simbolistica metabolelor alese conferă unicitate și har poeziei.

Îmbinând religia, filosofia și adevărurile psihologiei umane, Lucian Blaga oferă căi de cunoaștere a sinelui prin forme inedite de comunicare. Aceasta e și poezia Pax Magna!

\section{Bibliografie}

Bibliografie primară

Blaga, Lucian, Poezii, Ediţie îngrijită de G. Ivaşcu, Editura pentru Literatură, București, 1966.

Blaga, Lucian, „Spațiul mioritic” (Trilogia culturii), Ed. Humanitas, București, 2011.

Bibliografie critică

Borcilă, Mircea (coord.), Eonul Blaga, Întâiul veac, Culegere de lucrări dedicată Centenarului Lucian Blaga, Ed. Albatros, București, 1997.

Codoban, Aurel, „Un Blaga ignorant: Filosoful religiei”, în Eonul Blaga, Intâiul veac, Ed. Albatros, București, 1997.

Durand, Gilbert, Structurile antropologice ale imaginarului. Introducere în arhetipologia generală, traducere de Marcel Aderca, postfață Cornel Mihai Ionescu, Ed. Univers Enciclopedic, București, 2000.

\footnotetext{
${ }^{14}$ Eugen Todoran, Lucian Blaga,mitul poetic vol. 2, Ed. Facla, 1983, Timișoara, p.52 apud Mircea Eliade, Mitul reintegrării, p.47.

${ }^{15}$ Eugen Todoran, op. cit., p. 41.
} 
Fanache, Vasile, Chipuri tăcute ale veșniciei în lirica lui Blaga, Ed. Dacia, Cluj-Napoca, 2003.

Manolescu, Nicolae,Istoria critică a literaturii române, Ed. Paralela 45, Pitești, 2008.

Todoran, Eugen, Lucian Blaga, mitul poetic, vol 1, Ed. Facla, Timişoara, 1981. Todoran, Eugen, Lucian Blaga, mitul poetic, vol 2, Ed. Facla, Timișoara, 1983. 